\title{
Vitamin $E$ and fat supplementation of sows and the effect on tissue vitamin $E$ concentrations in their progeny
}

\author{
M Hidiroglou, E Farnworth, G Butler \\ Centre for Food and Animal Research, Agriculture Canada, Ottawa, K1A oC6 Canada
}

(Received 17 May 1993; accepted 15 September 1993)

\begin{abstract}
Summary - A study was conducted to evaluate the effects of supplementing the diets of gestating and lactating sows with 3 levels of vitamin E (22, 44 or $88 \mathrm{lU} / \mathrm{kg}$ ) and fat (no fat, $5 \%$ tallow, or $5 \%$ fish oil) on tissue vitamin $E$ concentrations in their progeny. Tissue levels of vitamin $E$ were examined at birth, and then at 14 and $28 \mathrm{~d}$ of age in the suckling piglets. Vitamin $\mathrm{E}$ concentration in all tissues at bith were very low (hip muscle, neck muscle, lung, brain, heart, kidney $<1.0 \mu \mathrm{g} / \mathrm{g}$ tissue). Piglet tissue vitamin $E$ levels at birth were influenced by the vitamin $E$ status of the maternal diet during gestation. The piglet tissue concentration of vitamin $E$ increased 2- to 3-fold by $14 \mathrm{~d}$ of age. Tocopherol concentrations greater than $3 \mu \mathrm{g} / \mathrm{g}$ tissue were found in the liver, lung, spleen, heart and kidney. Tissue vitamin $E$ concentrations of piglets from sows that had received fish oil were lower (significantly in 5 cases: $P<0.05$ ) than piglets from sows receiving tallow or no fat. Tocopherol concentrations in tissues, with the exception of the spleen, increased significantly $(P<0.05)$ with increased vitamin $E$ in the sows' diet.
\end{abstract}

sow / vitamin E / fat / tissue

Résumé - Effets de l'addition au régime de truies de vitamine $E$ et de graisses, sur les concentrations tissulaires en vitamine $\mathrm{E}$ de leur progéniture. Le but de cette étude était d'évaluer les effets de l'addition de vitamine $E(22,44$ ou $88 \mathrm{~g} / \mathrm{kg})$ et de graisses (sans graisse, $5 \%$ de suif ou $5 \%$ d'huile de poisson) au régime de truies gravides ou en lactation sur les concentrations tissulaires en vitamine $E$ de leur progéniture. Les taux de vitamine $E$ ont été mesurés à la naissance, puis à l'âge de 14 et $28 j$ chez les porcelets non sevrés. La concentration en vitamine $E$ de tous les tissus à la naissance était très faible (muscle de la hanche, muscle du cou, poumon, cerveau, cour, rein: $<1,0 \mu \mathrm{g} / \mathrm{g}$ de tissu). Les teneurs en vitamine $E$ chez le porcelet à la naissance étaient influencées par le statut vitaminique $E$ du régime de la truie pendant la gestation. Dès l'âge de $14 \mathrm{~h}$, les teneurs tissulaires étaient multipliées par 2 ou 3. Des taux de tocophérol supérieurs à $3 \mu \mathrm{g} / \mathrm{g}$ de tissu ont été observés dans le foie, le poumon, la rate, le cour et le rein. Les taux tissulaires de vitamine $E$ étaient plus faibles (de façon significative à $\mathrm{P}<0,05$ dans 5 cas) chez les porcelets nés de truies ayant reçu de l'huile de poisson, par rapport à ceux nés de truies ayant reçu du suif ou aucune graisse. $\dot{A}$ l'exception des teneurs dans la rate, toutes les teneurs tissulaires en tocophérol augmentaient significativement $(\mathrm{P}<0,05)$ avec l'apport alimentaire de vitamine $E$ chez la truie. 


\section{INTRODUCTION}

Recently Mahan (1991) reported that small quantities of vitamin $E$ can traverse pig placental tissue. Mammary transfer was a more effective way of providing $\alpha$ tocopherol to the nursing pig. Londenslager et al (1986) indicated that the newborn is dependent on colostrum $\alpha$ tocopherol to prevent the onset of deficiency postnatally in the young piglet. Consequently, if colostrum has a lowered $\alpha$ tocopherol content because of various nutritional and environmental factors, the neonate might indeed benefit from a tissue reservoir of $\alpha$-tocopherol at birth. To date, a comprehensive study of the effects of the gestation and lactation diet on the tissue status of piglets at birth and during lactation, has not been reported.

The work described below was carried out as an extension of previous work ( $\mathrm{Hi}-$ diroglou et al, 1993) to increase our knowledge of the physiological behavior of vita$\min E$ in the various tissues of piglets following birth. The objective of this study was to provide information on the patterns of $\alpha$-tocopherol in a wide variety of piglet tissues in the neonatal period. Piglets nursed sows that had been fed different dietary lipids and different vitamin $E$ levels during the gestation and lactation period. Lipids for the maternal diets were chosen that differed in their fatty acid composition to determine whether this influenced the vitamin $E$ status of piglets at the different measurement periods.

\section{MATERIALS AND METHODS}

\section{Experimental design and diets}

Gilts were selected from a minimum disease herd which had been fed a pelleted standard growing diet containing $27 \mathrm{IU} / \mathrm{kg}$ vitamin $\mathrm{E}$ (major ingredients: corn, $43 \%$; barley, $35 \%$; soybean meal ( $43 \%$ protein), $3 \%$, bran $5 \%$ ) until they reached $95 \mathrm{~kg}$ body weight. They were then fed a control diet containing $24 \mathrm{lU} / \mathrm{kg}$ vita$\min E$ at the rate of $2 \mathrm{~kg} / \mathrm{d}$. Detailed information on diets of sows is provided elsewhere (Hidiroglou et al, 1993).

The study was a split-plot design involving 3 types of dietary fat (whole-plot treatment) and 3 vitamin $E$ supplementation levels (sub-plot treatment). On day 57 of gestation, gilts were randomly assigned to a pelleted gestation diet containing 1 of the 3 vitamin E levels $(22,44$ or 88 $\mathrm{IU} / \mathrm{kg}$ ) and $0.1 \mathrm{mg} / \mathrm{kg}$ selenium diet. Over time, 3 replicates of 3 sets of 3 sisters were randomly assigned to a fat type (no fat, $5 \%$ tallow, or $5 \%$ fish oil) throughout gestation and lactation. All vitamin $E$ added to the diet was in the form of DL$\alpha$-tocopherol acetate. Pregnancies were allowed to proceed to full term and births were attended when possible. The above was repeated until 27 gilts and completed the experiment.

\section{Vitamin E tissue analysis}

Piglets were sacrificed at $0,14,28 d$ of age and all tissues were immediately frozen and stored at $-20^{\circ} \mathrm{C}$ until analysis. The time- 0 piglets were removed from the sow as soon after birth as possible; all piglets were less than $8 \mathrm{~h}$ old and most had not received colostrum. Tissues for vitamin $E$ analysis were prepared according to Burton et al (1985) and analyzed by HPLC, according to McMurray and Blanchflower (1979). Tissue vitamin $E$ levels were expressed as $\mu \mathrm{g} / \mathrm{g}$ wet tissue.

\section{Statistical analysis}

The effects of fat in the diet and vitamin E supplementation on various tested variables were analyzed for each killing date as a split-plot design with dietary fat as the whole plot treatment applied to 3 sisters of a litter and dietary vitamin $E$ as the subplot treatment applied at a different level of each sister. The following linear model was used: $Y_{i j k}=u+r_{i}+f_{i}+r_{i j}+v_{k}+v f_{j k}+e_{i j k}$. Here, $Y$ is the measured trait at a specific time; $u$ is the overall mean; $r$ is the replicate (over 
time) effect; $f$ is the effect of the dietary fat supplement; $v$ is the effect of vitamin $E$ supplement; $v f$ is the effect of interaction of the 2 supplements (fat and vitamin E); and $e$ is the error. For the vitamin $\mathrm{E}$ concentration, since vf was not significant in any case, it was pooled with error to give a sub-plot error estimate (at least 13 degrees of freedom). Least-squares means from this analysis and the linear contrast for vitamin $E$ are reported. Piglet means for each sow and time were analyzed rather than individual piglet values as there was a clear indication that the among-litter error was greater than the amongpiglet error. All analyses were carried out using SAS (1989).

\section{RESULTS AND DISCUSSION}

Table I contains piglet body and organ weight data. The data are summarized on the basis of maternal dietary vitamin $E$ level. Only the spleen weight at day 0 was significantly affected by the maternal dietary vitamin $E$ level, but disappeared when spleen weights were normalized for piglet body weight. When the effect of the type of fat in the maternal diet was tested, lung weight at day 0 (fish oil group $27.59 \mathrm{~g}$, no fat group $20.71 \mathrm{~g}$, tallow group $17.92 \mathrm{~g}$ ) was significantly $(P<0.05)$ affected, even after lung weight was divided by body weight. There was a similar effect for the eye at day 0 (fish oil $2.28 \mathrm{~g}$, no fat $2.09 \mathrm{~g}$, tallow $1.97 \mathrm{~g}$ ) and brain at day 28 (fish oil $51.49 \mathrm{~g}$, no fat $48.80 \mathrm{~g}$, tallow $51.85 \mathrm{~g}$ ) but these were not significant $(P<0.05)$ on a percentage of body weight basis. These results suggest the level of vitamin $E$ or the type of fat in the maternal diet may affect some internal organ weights.

The experiment was designed to test the effects of the dietary fat the sow was receiving on the vitamin $E$ status of her piglets. These data are presented in table II. With only 2 exceptions (brain, at day 28 and spleen at day 0 ) the tissues of the piglets nursing sows receiving fish oil had low- er tissue vitamin $\mathrm{E}$ concentrations than piglets nursing sows than had been fed tallow or no fat. This is consistent with reports that the requirement for vitamin $E$ increases when polyunsaturated fatty acids are included in the diet (Coelho, 1991). Effects of the maternal dietary fat were significant on lung vitamin $E$ day 14 and day 28 , liver, day 28 , neck muscle, day 28 , and spleen, day 14 . Generally, as lactation progressed, the differences between the fish oil group and the other 2 groups became more apparent.

In figures 1-7 the $\alpha$-tocopherol tissue concentrations in the various piglet organs and tissues are displayed. This method of presenting tocopherol concentrations in the various tissues permits an easy comparison between the different maternal vitamin $\mathrm{E}$ dietary concentrations as well as illustrating the effect of piglet age on piglet vitamin $\mathrm{E}$ tissue concentrations.

Body $\alpha$-tocopherol is distributed throughout all tissues of the body (Bartolotti et al, 1990). Our tissue data (figs 1-8) show that piglets sampled before they have had colostrum have a low vitamin $E$ status. Previous findings (Hidiroglou et al, 1969) in pregnant ewes and fetal lambs have demonstrated that $\alpha$-tocopherol crosses the placenta in very limited amounts. However, the vitamin E status of the lactating ewe and especially its colostrum and milk vitamin $E$ content greatly influence the tissue $\alpha$-tocopherol values in the newborn lamb. Similar reasoning was used by Dvorak (1974) to explain low levels of vitamin $E$ in neonatal pig blood plasma. Our low $\alpha$-tocopherol concentrations in the various tissues of the newborn pig are in agreement with Urbanova and Toulova (1975) and Kelly et al (1992) who reported low supply of tocopherol to the fetal piglet or guinea piglet from the maternal circulation. Schlotke et al (1978) reported that the vitamin $E$ status of newborn pigs before ingestion of colostrum is indepen- 


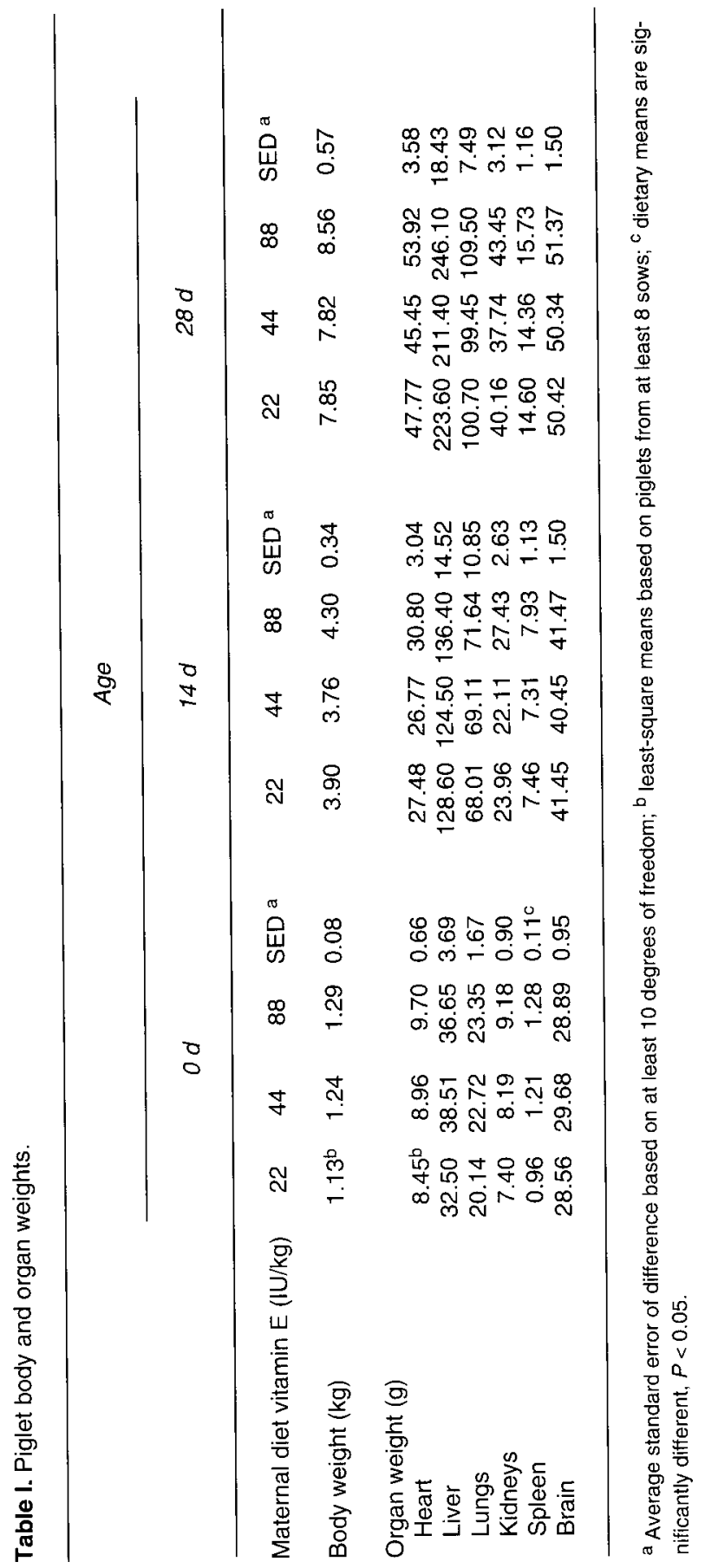




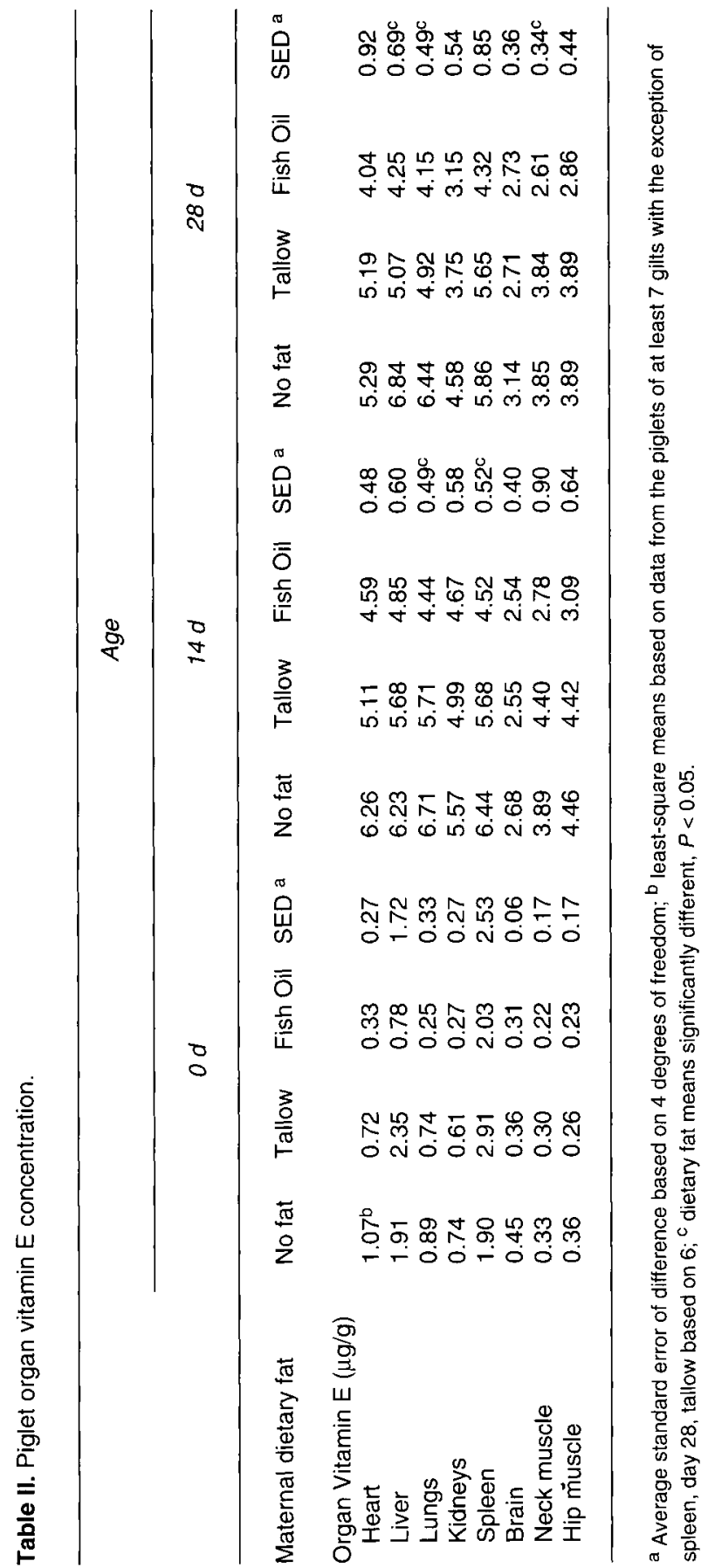



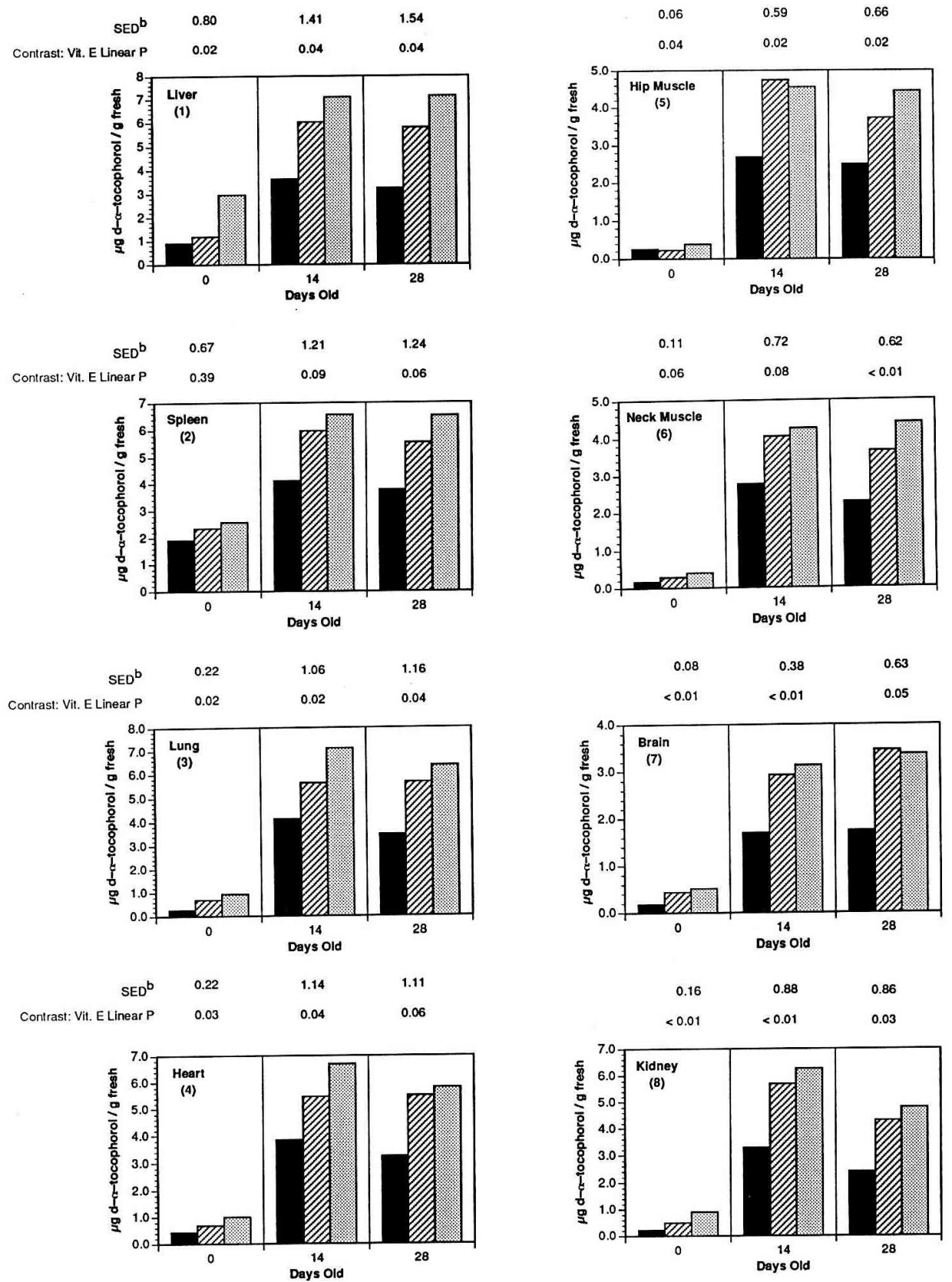

Sow dietary vit E

$221.0 / \mathrm{kg} \quad \square 441.0 . / \mathrm{kg}$ 成 $881 . U / \mathrm{kg}$ 
dent of vitamin $E$ supplied to the dam. In contrast, our data (figs 1-8) indicates a trend for higher tissue levels in piglets born to sows receiving higher levels of vitamin $\mathrm{E}$ in their gestation diet; only the spleen vitamin $\mathrm{E}$ concentrations were unaffected $(P>$ 0.25 ) in newborn (day 0) piglets as a result of high vitamin $E$ in the maternal diet during gestation.

The data presented in figures 1-8 show the $\alpha$-tocopherol concentrations in the various piglet tissues from $0-28 \mathrm{~d}$ of age. Most tissues had a rate of accumulation from 0 to $14 \mathrm{~d}$ which was consistently and significantly higher in the piglets born from sows fed the higher vitamin $E$ concentrations. Age had a significant effect $(P<0.05)$ on tocopherol tissue concentration in all tissues. The vitamin $E$ tissue concentration in the tissues analyzed did not change significantly $(P<0.05)$ between 14 and $28 \mathrm{~d}$ after birth in any group. The rise in vitamin $E$ content in the tissues of the piglets is a result of the intake of vitamin $E$ from colostrum and milk. We have been able to increase maternal plasma and milk vitamin $\mathrm{E}$ content by increasing the vitamin $E$ content of the maternal diet (Hidiroglou et al, 1993). This, in turn, raised piglet blood and tissue tocopherol concentrations.

Colostrum is higher in tocopherol concentration than mature milk (Loudenslager et al, 1986; Mahan, 1991; Hidiroglou et al, 1993). This is perhaps a protective mechanism as the animal makes the abrupt change from a low fat (in utero) to a high fat (sows milk) diet. The low tissue tocopherol levels therefore quickly rise due to the intake of colostrum and continue high as the intake of milk increases during lactation.
Machlin (1984) reported that in terms of total amounts accumulated, skeletal muscle accounts for most of the body's tocopherol. Our data show that heart muscle vitamin $E$ concentration per gram tissue was higher than skeletal msucle. The concentration of $\alpha$-tocopherol in piglet skeletal muscles varied and is probably related to their fat content and therefore to their ability to store more vitamin E. Hidiroglou et al (1988) reported that the tocopherol concentration in the muscle tissue and the brain were the lowest in the body. The slower increase of the vitamin E concentration in the piglet musculature, in comparison to liver and heart muscle, could indicate not only a lower build-up, but also a higher turnover. According to Jensen et al (1990) the concentration of vitamin $E$ in skeletal muscle reflects the long-term nutritional history of an animal rather than the immediate nutritional status.

Jensen et al (1988) reported that the liver had a remarkable storage capacity for vitamin $E$. Because the liver is a target organ for hepatica dietica, a major symptom of vitamin E deficiency in pigs, it is of great interest to study the rate of accumulation of vitamin $E$ in the liver of the growing pig in detail.

Our data showed that in piglets left with the sow, liver $\alpha$-tocopherol increased nearly 3-fold between days 0 and 14 after birth. This is consistent with the report of Machlin and Gabriel (1982) that showed liver tissue accumulated $\alpha$-tocopherol at a much faster rate then other tissue, except lung. In our study, there were significantly higher vitamin $E$ concentrations (linear contrast for sow dietary vitamin level $P=$ $0.02)$ in the livers of piglets born from sows

Figs 1-8. Tissues $\alpha$-tocopherol concentration ( $\mu \mathrm{g} \alpha$-tocopherol/g of fresh tissue) in piglets born to sows receiving $22,44,88 \mathrm{lU} / \mathrm{kg}$ vitamin $E$ diet. Included are standard error of difference values (SED) and $P$ values for the test of a linear trend for the individual tissue vitamin $E$ concentration with respect to sow diet vitamin $E$ level at the 3 sampling times $(0,14,28 \mathrm{~d})$. 
with higher dietary vitamin $E$ intake (88 IU) than those fed 44 or 22 IU. The liver may be a depot for vitamin $E$, releasing $\alpha$ tocopherol into the blood immediately following birth.

Roth and Kirchgessner (1975) stated that the vitamin $E$ status of the piglet can be directly determined from $\alpha$-tocopherol concentration in the liver. Rousseau et al (1957) reported that plotting the data for plasma vitamin $E$ against the associated log of the liver vitamin $E$ concentrations in piglets showed a linear relationships. This finding, allows, according to Rousseau et al (1957), the general tocopherol status of the animal to be established from a blood sample.

Our data (from all dietary treatments and all time periods) indicated that the log of the plasma vitamin $E$ concentration was linearly related to the log of the liver vita$\min E$ concentration. The correlation between the logs of piglet liver and plasma $\alpha$-tocopherol concentrations (for all dietary treatments) was $0.72,0.45$ and 0.26 on days 0,14 and 28 , respectively, indicating a diminishing relatonship with age. Charmley et al (1992) found in cattle that the relationship between plasma and hepatic tocopherol concentration is influenced by many factors (breed, physioloical state, tocopherol status, plasma lipid) in addition to plasma concentration.

The piglet is born with low levels of vitamin $E$ stores, but these may be influenced by the vitamin $E$ status of the maternal diet. During the lactation period all piglet tissues increased in vitamin $E$ due to the intake of colostrum and milk. This is also a time of rapid increase in body fat due to the intake of sow's milk which is high in fat. These 2 events may be linked. The many functions of vitamin $E$ in the body increases the importance of an adequate supply of vitamin $E$ during this stage of early development and growth.

\section{ACKNOWLEDGMENTS}

$S$ Winter made a significant contribution to this work. $M$ Keough carried out the vitamin $E$ analyses.

\section{REFERENCES}

Bartolotti A, Traina GL, Barzago MM, Celardo A, Bonati M (1990) Placental transfer and tissue distribution of vitamin $E$ in pregnant rabbits. Biopharm \& Drug Dispos 11, 679-688

Burton GW, Webb A, Ingold KU (1985) A mild rapid and efficient method of lipid extraction for use in determining vitamin E/lipid ratios. Lipids 20, 29-39

Charmley E, Hidiroglou N, Ochoa LR, McDowell LR, Hidiroglou M (1992) Plasma and hepatic $\alpha$-tocopherol in cattle following oral or intramuscular supplementation. J Dairy Sci 75 , 804-810

Coelho MB (1991) Functions of vitamin E. In: Vitamin $E$ in Animal Nutrition and Management (BASF, Parsippary, NJ) pp 11-17

Dvorak M (1974) Levels of vitamin $E$ in the blood plasma of suckling and weaned pigs. Acta Vet Brno 43, 103-110

Hidiroglou M, Hoffman I, Jenkins KJ (1969) Selenium distribution and radiotocopherol metabolism in the pregnant ewe and fetal lamb. Can J Physiol Pharmacol 47, 953-962

Hidiroglou M, Laflamme LF, McDowell LR (1988) Blood plasma and tissue concentration of vitamin $E$ in beef cattle is influenced by supplementation of various tocopherol compounds. J Anim Sci 66, 3227-3224

Hidiroglou M, Farnworth E, Butler G (1993) Effects of vitamin $E$ and fat supplementation on concentration of vitamin $\mathrm{E}$ in plasma and milk of sows and in plasma of piglets. Intern J Vit Nutr Res 63, 180-187

Hoppe $P$ (1988) Alpha-tocopherol as a radical scavenger. 3rd Animal Nutr Forum. BASF Ludwigshaten

Jensen $\mathrm{M}$, Hakkarainen $\mathrm{J}$, Lindholm $\mathrm{A}$, Jonsson $L$ (1988) Vitamin $E$ requirement of growing swine. J Anim Sci 66, 3101-3111

Jensen M, Lindholm A, Hakkarainen J (1990) The vitamin $E$ distribution in serum, liver, adi- 
pose and muscle tissues in the pig during depletion and repletion. Acta Vet $J$ Scand 31, 129-136

Kelly FJ, Safavi M, Cheeseman K (1992) Tissue $\alpha$-tocopherol status during late fetal and early neonatal life of the guinea pig. Br $J$ Nutr 67 , 457-462

Loudenslager MJ, Ku PK, Whetter PA, Ullrey DE, Whitehair CK, Stowe HO, Miller ER (1986) Importance of diet of dam and colostrum to the biological antioxidant status and parental iron tolerance of the pig. $J$ Anim Sci 63, 1905-1924

Machlin LJ (1984) Vitamin E. In: Handbook of Vitamins: Nutritional, Biochemical and Clinical Aspects (LJ Machin, ed) M Dekker, NY 99-145

Machlin LJ, Gabriel E (1982) Kinetics of tissue $\alpha$-tocopherol uptake and depletion following administration of high levels of vitamin $E$. Ann NY Acad 393, 48-60

Mahan DC (1991) Assessment of the influence of dietary vitamin $E$ or sow and offspring in three parities: reproductive performance, tissues tocopherol, and effect on pregnancy. $J$ Anim Sci 69, 2904-2917

McMurray $\mathrm{CH}$, Blanchflower WJ (1979) Application of high-performance liquid chromatography fluorescence method for the liquid deter- mination of $\alpha$-tocopherol in the plasma of cattle and pigs and its comparison with direct fluorescence and high-performance liquid chromatography ultra-detection methods. J Chromatog 178, 525-531

Rousseau JE, Dicks MW, Teichman R, Helmboldt CF, Bacon EL, Pouty RM, Dolge KL Eaton HD, Jungherr EL, Beall G (1957) Relationships between plasma, liver and dietary tocopherol in calves, lambs and pigs. J Anim Sci 16, 612-622

Roth EX, Kirchgessner M (1975) Blood and tissue vitamin $E$ concentrations in growing pigs at different $\mathrm{DL}-\alpha$-tocopherol acetate supplementation rates. Intern $Z$ Vit Ern Forschung $45,331-341$

SAS Institute, Inc (1989) SAS/STAT User's Guide, version 6, volume 2. SAS Institute. Cary NC, pp 846

Schlotke B, Busch L, Kochi F (1978) Studies on the effect of vitamin $\mathrm{E}$ deficient diet in sows during pregnancy on the vitamin $E$ status of newborn piglets. Zentralbl Vet Med A 25 , 474-484

Urbanova J, Toulova M (1975) Lipid peroxidation in vitro and tocopherol levels in the tissues of suckling and weaned piglets. Acta Vet 44, 17-22 